\title{
DEVELOPMENT OF ENZYMATIC BIODIESEL FROM VEGETABLE OIL AND QUANTIFICATION OF FATTY ACID BUTYL ESTERS
}

\author{
Dilip Kumar* and Bhawna Verma \\ Department of Chemical \& Technology, \\ Indian Institute of Technology (BHU), Varanasi-221005, India \\ *E-mail: dilip.rs.che14@itbhu.ac.in
}

\begin{abstract}
Biodiesel was produced by enzymatic transesterification of soybean oil with isobutanol esterifying agent and Lipase (Pseudomonas cepacia) as a biocatalyst. Fourier transform infrared spectroscopy (Thermo-Nicolet mode 5700) was employed as an analytical technique for the quantification of fatty acid butyl ester content in the produced biodiesel. The spectra of produced butyl biodiesel found in the 500-4000 per $\mathrm{cm}$ region, along with a declaration of 4 per $\mathrm{cm}$. The method developed by Zagonel was used for quantitative analysis. Results of Fourier transform infrared spectra for oil and biodiesel shows a strong band at about $1739.4 \mathrm{~cm}^{-1}$ is because of the deformation(stretching) of ester $\mathrm{C}=\mathrm{O}$ axial, two medium bands at 1002.9 and $1039.3 \mathrm{~cm}^{-1}$ related to the $\mathrm{C}-\mathrm{O}$ bond stretching and a small band at $963.4 \mathrm{~cm}^{-1}$ related to C-C stretching. The strong band at about $1739.4 \mathrm{~cm}^{-1}$ was increased with time and that is recognized to the quantity of glycerol substitution present in fatty acid by butoxy radicals (butanolysis). The soybean oil strong band peak is at $1743.6 \mathrm{~cm}^{-1}$ and soybean butyl diesel strong band peak is at $1739.4 \mathrm{~cm}^{-1}$ shifting peaks indicates the transesterification. The peak of transmittance for biodiesel was different from the respective peak of soybean oil. The highest value of absorbance band at wave number $1739.4 \mathrm{~cm}^{-1}$ was used for the calculation of the concentration of ester present in the butyl biodiesel layer.
\end{abstract}

Keywords: Lipase, Transesterification, Butyl biodiesel, and Soybean oil.

(C) RASĀYAN. All rights reserved

\section{INTRODUCTION}

The global climate change due to conventional fuels and their depletion has attracted the pursuit of sustainable energy sources in today's era. Different environment-friendly technologies like plug-in electrics, hybrids, biofuels, compressed fossil fuel or hydrogen-fuelled vehicles are being developed as an answer to the current problem. Among this biofuel production has emerged as a paradigm in Asian countries. ${ }^{1}$ Considering the environmentally friendly aspect and the energy security provided by biofuels, large subsidies are being provided for its growth. In developing countries biofuels are viewed as a potential supply to the speed-up rural development and make employment opportunities. To meet the future energy demand, palm oil methyl ester may be taken as an alternative to nonconventional renewable energy. ${ }^{2}$ Biodiesel, a biofuel, composed of alkyl group esters of fatty acids, are produced by cracking, microemulsification and transesterification. ${ }^{3}$ Transesterification is the most common method for production, where reaction of triglycerides from seed oils (e.g., sunflower, jatropha, soybean, karanja and castor etc. ${ }^{4}$ ) with a short-chain alcohol (e.g., methanol, ethanol, propanol or butanol) take place. Vegetable oils can be regarded as a quite good substitute to diesel because of their similarities in properties with diesel. Presently, vegetable oils are used to produce biodiesel for commercial purpose through the process of esterification. ${ }^{5}$ Commercially this reaction occurs at an elevated temperature using chemical catalysts, acidic (sulphuric acid, sulphonic acid, etc.) or alkaline $(\mathrm{KOH}, \mathrm{NaOH})$ in nature. ${ }^{6}$ Although high yields of biodiesel with low production cost are obtained with chemical catalysts, some limitations like soap development, creation of acid or basic waste effluents, corrosive nature of acids, high operational temperatures are encountered. ${ }^{7,8}$ Biological catalysts such as lipase enzymes can be considered as one of the alternatives as they are environmentally friendly, reduced cost as lesser downstream 
RASĀYAN J. Chem.

Vol. 11 | No. 1 |187-194 | January - March | 2018

processing required and with no soap formation and side reaction. ${ }^{9}$ The operating temperature gets reduced to approx. $40^{\circ} \mathrm{C}$ from $100-200^{\circ} \mathrm{C}$ with chemical catalysts. The milder conditions considerably reduce the energy consumption. ${ }^{10}$ Lipase is the enzymes that catalyze each esterification and transesterification reactions, have a high catalytic activity in water-deficient media. As a result, transesterification reaction catalyzed by the enzyme can be carried out in non-aqueous environments like organic and ionic liquids, solvent-free systems, gaseous media and supercritical fluids. Organic solvents have various advantages like increase reactant solubility, reduced medium viscosity, homogeneous media favors the mass transfer, the thermodynamic equilibrium shifted to favor the synthesis and the byproducts can be recovered easily. However, these solvents may affect the activity of the enzyme. At present, lipases are not extensively employed in commercial process due to their high price and high latent period. ${ }^{11}$

The deserves of this method are at the same time lipase catalysis (Triglyceridesalcoholysis and Free Fatty Acids esterification), simple glycerol recovery, use of high free fatty acid content feedstock and the smallest amount of wastewater generated. Immobilization of protein may be a well-known approach for industrial scale applications as a result of the immobilization permits recovery and re-use of the enzymes so reducing cost. ${ }^{12}$ Many techniques are offered for immobilization of enzymes viz; covalent binding or physical adsorption onto solid carriers, physical entrapment inside polymer matrices. ${ }^{13}$ Recently Enzymes are immobilized on nanofibrous carriers as either surface attachment on fibers or encapsulation in fibers. ${ }^{14}$ Surface attachment refers to physical surface assimilation or covalent attachment of lipase. It has been according to that butyl-biodiesel have equivalent cetane numbers to the methyl group esters of similar fatty acids. ${ }^{15}$ Butyl esters showed poorer crystallization temperatures than methyl group esters. ${ }^{16}$ The extent of smoke density from a diesel engine can be reduced by butanol diesel blends. ${ }^{17}$ These clearly indicate the potential of butyl-biodiesel. The current study is to optimize the key method parameters for the synthesis of butyl biodiesel from soybean oil and impact of iso-butanol on operational stability of genus Pseudomonas cepacia lipase enzyme.

\section{EXPERIMENTAL}

\section{Materials and Methods}

The soybean oil was purchased from local market Varanasi and used as a source of triglycerides. Lipase from Pseudomonas cepacia was purchased from Sigma- Aldrich. Iso-butanol was purchased from Qualigens Fine Chemical Ltd. Potassium hydroxide pellets were purchased from S.D. Fine Chem. Limited. The Fourier transform infrared spectroscopy (FTIR-Thermo-Nicolet mode 5700) analysis of soybean oil and biodiesel is given in Table-1. Other chemicals and solvents used in this study were of analytical grade and procured from the Qualigens Fine Chemical Ltd.

Table-1: FTIR analysis of soybean oil and biodiesel

\begin{tabular}{c|c|c|c|c|c}
\hline \multicolumn{3}{c|}{ Soybean oil } & \multicolumn{3}{c}{ Soybean biodiesel } \\
\hline $\begin{array}{c}\text { Wave number range } \\
\left(\mathrm{cm}^{-1}\right)\end{array}$ & Type of bond & Group & $\begin{array}{c}\text { Wave number range } \\
\left(\mathrm{cm}^{-1}\right)\end{array}$ & Type of bond & Group \\
\hline $3000-2850$ & $\begin{array}{c}\text { C-H } \\
\text { stretching }\end{array}$ & Alkanes & $725-700$ & C-H rock & Alkanes \\
\hline $1000-650$ & =C-H bend & Alkenes & $1300-1000$ & C-O stretching & Esters \\
\hline $725-720$ & C-H rock & Alkanes & $1750-1700$ & C=O stretching & Esters \\
\hline $1370-1350$ & C-H rock & Alkanes & $3300-2500$ & O-H & $\begin{array}{c}\text { Carboxylic } \\
\text { acid }\end{array}$ \\
\hline $1470-1450$ & C-H bending & Alkanes & $3000-2850$ & C-H stretching & Alkanes \\
\hline
\end{tabular}

\section{Experimental setup for biodiesel production}

The experiment was performed in water batch reactor, as shown in Fig.-1. The following equipment was used during the experiments. Three necked glass reactor, electric heater for the batch reactor, water bath 
with an overhead stirrer and temperature indicator, micropipette, Erlenmeyer flask, Thermometer, Funnel, Centrifuge apparatus, centrifuge tube, Fourier transform infrared spectroscopy etc.

\section{Butyl biodiesel synthesis}

Production of butyl biodiesel was carried out in $250 \mathrm{~mL}$ round bottom flask at temperature $40^{\circ} \mathrm{C}$ for $48 \mathrm{~h}$ on a water bath shaker. Soybean oil was filtered using filter paper (Whatman No.42) and heated at $100^{\circ} \mathrm{C}$ for $15 \mathrm{~min}$ to eliminate moisture in the vegetable oil. The reaction mixture containing $10.1442 \mathrm{~g}$ of soybean oil, $0.00279 \mathrm{~g}$ lipase from Pseudomonas cepacia and $4.8235 \mathrm{~g}$ of Iso-butanol (6:1iso-butanol to oil molar ratio) was mixed in round bottom flask. Iso-butanol was mixed to the reaction mixture at regular time intervals of $24 \mathrm{~h}$ for butanolysis in round bottom flask. The reaction mixture containing butyl esters was analyzed by Fourier transform infrared spectroscopy (FTIR) (Thermo-Nicolet mode 5700).

\section{Lipase activity using olive oil as substrate}

The activity of lipase was exhibited by titrimetry utilizing emulsion of olive oil which was set up by blending $25 \mathrm{~mL}$ of the olive oil and $75 \mathrm{~mL}$ of $7 \%$ Arabic gum arrangement by the process of sonication for $5 \mathrm{~min}$. The response blend containing $5 \mathrm{~mL}$ of emulsified olive oil, $4 \mathrm{~mL}$ of $50 \mathrm{mM}$ Tris- $\mathrm{HCl}$ buffer, $\mathrm{pH} 8.0,1 \mathrm{~mL}$ of $110 \mathrm{mM} \mathrm{CaCl}_{2}$ and $1 \mathrm{~mL}$ of lipase $(5 \mathrm{mg} / \mathrm{mL})$ was undergone the process of incubation at $40^{\circ} \mathrm{C}$ for $30 \mathrm{~min}$ submerged shower shaking at $150 \mathrm{rpm}$. The response was quickly ceased suddenly after the hatching time frame by the expansion of $15 \mathrm{~mL}$ acetone: $\mathrm{C}_{2} \mathrm{H}_{5} \mathrm{OH}$ blend $(1: 1 \mathrm{v} / \mathrm{v})$, and titration of the discharged free fatty acids were performed with $50 \mathrm{mM} \mathrm{NaOH}$. One unit (U) of enzyme activity was defined as the quantity that discharged $1 \mu \mathrm{mol}$ of fatty acid for every min. ${ }^{18}$

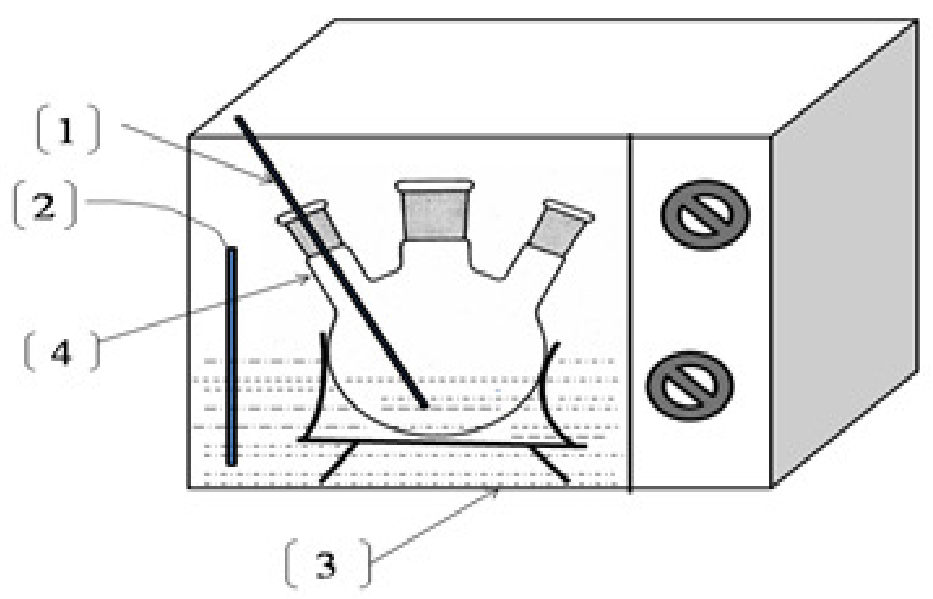

Fig.-1: Schematic diagram for batch reactor system (1) Thermometer; (2) Thermocouple in the water bath; (3) Water bath shaker; (4) Three neck round bottom flask

\section{Effect of pH on the lipase activity}

The $\mathrm{pH}$ scale result on the activity profiles was examined by olive oil assay amid a $\mathrm{pH}$ scale change of 4.0 to 10.0 utilizing totally dissimilar buffer at $50 \mathrm{mM}$ concentration. For activity, one milliliter of catalyst $(5 \mathrm{mg} / \mathrm{mL})$ was blended with $4 \mathrm{~mL}$ of different buffer and incubation was taken place for $30 \mathrm{~min}$. at $40^{\circ} \mathrm{C}$. From that point onward, the activity was executed as represented by the activity of olive oil.

\section{Effect of temperature on the lipase activity}

Temperature effect on the activity of the protein was studied by finishing the catalyst reaction at totally unique temperatures inside the shift of 30 to $80^{\circ} \mathrm{C}$ at $\mathrm{pH}$ scale 8.0 utilizing the buffer $(50 \mathrm{mM})$ of Tris$\mathrm{HCl}$. The temperature of the enzyme was tried by pre-incubated the protein $(5 \mathrm{mg} / \mathrm{mL})$ at totally extraordinary temperatures beginning from 30 to $80^{\circ} \mathrm{C}$ for $30 \mathrm{~min}$. From that point forward, the assay was used as represented to for olive oil assay. 


\section{Effects of reaction $\mathrm{pH}$ on relative activities}

\section{RESULTS AND DISCUSSION}

In the current work, the basic enzyme was most dynamic in $\mathrm{pH}$ go-between, $7.0-9.0$. The impact of $\mathrm{pH}$ scale on the basic enzyme activity was dictated by measuring the catalyst activity at different $\mathrm{pH}$ esteems running from 4 to 10 at $40^{\circ} \mathrm{C}$ for 30 min utilizing diverse buffer viz., buffer of $50 \mathrm{mM}$ Citrate phosphate ( $\mathrm{pH}$ 4.0-6.0), $50 \mathrm{mM}$ Tris- $\mathrm{HCl}$ buffer ( $\mathrm{pH} 7.0$ - 8.0), 50mM Carbonate-bicarbonate buffer (pH 9.0 - 10.0). This enzyme activity was found to be highest in $\mathrm{pH} 8.0$ (Fig.2). The proteins from F. oxysporumf. sp. Lini was steady in $\mathrm{pH}$ go 6.0 to 7.0 and had ideal activity at $\mathrm{pH} 7.0 .{ }^{19} \mathrm{On}$ another hand, few proteins from Bacillus thermoleovorans were found to be the most active at $\mathrm{pH} 9.0$ to 10.0 and stable in a wide scope of $\mathrm{pH}$ esteems 5.0 to11.0, holding over $80 \%$ of activity after $26 \mathrm{~h}$ at $30^{\circ} \mathrm{C} .{ }^{20}$

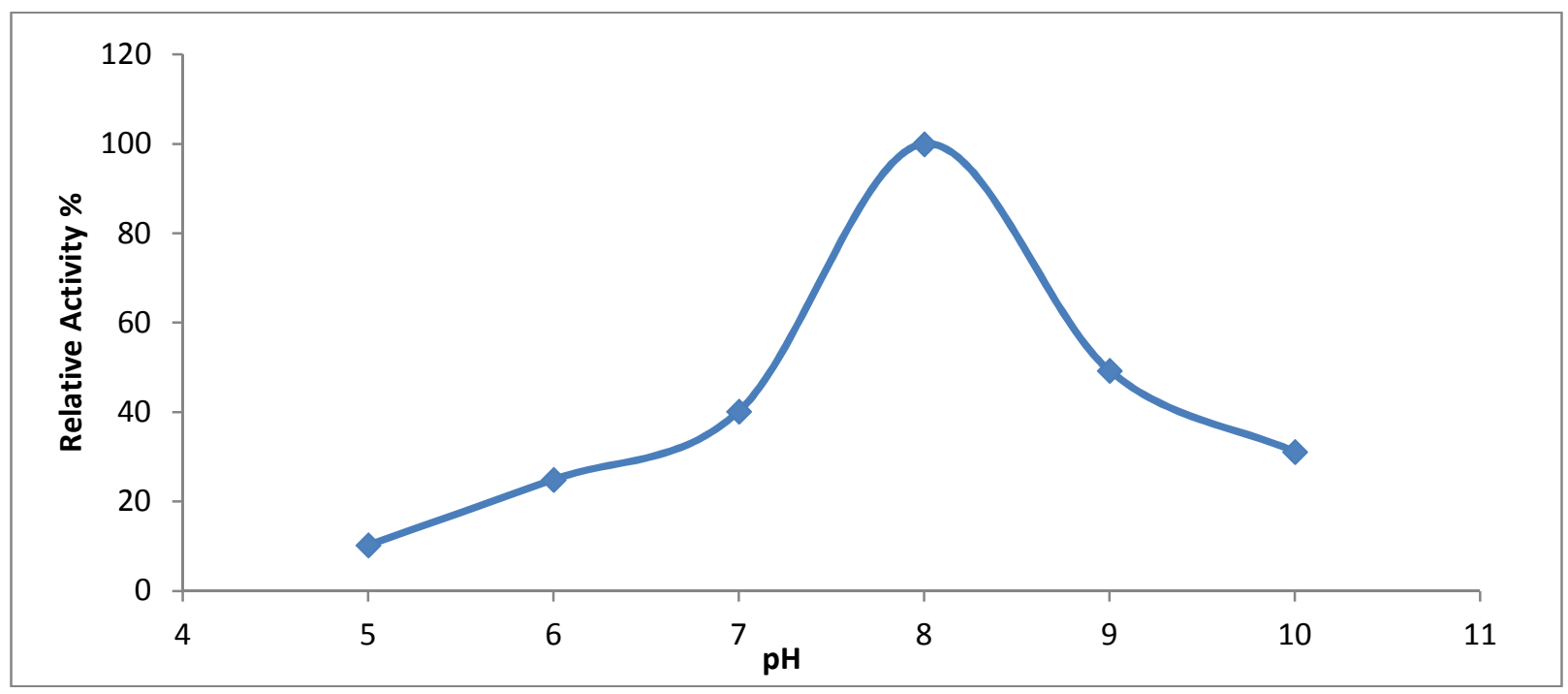

Fig.-2: Effects of reaction $\mathrm{pH}$ on relative activities

\section{Effect of reaction temperature on relative activities}

At low temperatures, the speed of most catalyst reactions follows associate Arrhenius-type equation and a rise in temperature yields to higher rates. However, at high temperatures thermal denaturation of the catalyst takes place and therefore the conversion decreases. According to the manufacturer, Pseudomonas cepacia ought to use from thirty to $50{ }^{\circ} \mathrm{C}$, so experiments were conducted at completely different temperatures at intervals that range: $30-80{ }^{\circ} \mathrm{C}$, with associate degree $6: 1$ isobutanol to the vegetable oil molar quantitative relation. As are often seen in Fig.3, the reaction at $40{ }^{\circ} \mathrm{C}$ provides the best yield at forty eight $h$. the same behavior was found by Shimada et al., whereas victimization vegetable oil and methyl alcohol. ${ }^{21}$ Therefore, the studied temperatures have a very important role in the initial rates, however, don't improve the yield nor denaturalize the enzyme, therefore $40{ }^{\circ} \mathrm{C}$ was chosen as an operational condition within the resulting experiments. The catalyst was found to move on a large variety of natural substrates of either vegetable or animal origin. It hydrolyzed varied natural lipids at completely different rates.

\section{Analysis of butyl ester}

In the present work soybean oil and butyl esters (butyl biodiesel) were investigated by Fourier transform infrared (Thermo-Nicolet mode 5700). The spectra of delivered butyl biodiesel were gotten in the 500$4000 \mathrm{~cm}^{-1}$ area, at a resolution of 4 for each $\mathrm{cm}$. Midpoints of 32scans were recorded utilizing a multibounce ATR. The technique created by Zagonel was utilized for quantitative investigation. ${ }^{22}$ Results of Fourier transform infrared spectra for oil and biodiesel are showing in fig.-4 and 5. Detail analysis is shown in Table-1. The spectrum shows a strong band at about $1739.4 \mathrm{~cm}^{-1}$ recognized to the 
RASĀYAN J. Chem.

Vol. 11 | No. 1 |187-194 | January - March | 2018

deformation(stretching) of ester $\mathrm{C}=\mathrm{O}$ axial, two medium bands at 1002.9 and $1039.3 \mathrm{~cm}^{-1}$ related to the $\mathrm{C}-\mathrm{O}$ bond stretching and a small band at $963.4 \mathrm{~cm}^{-1}$ correlated to the $\mathrm{C}-\mathrm{C}$ stretching. The strong band at about $1739.4 \mathrm{~cm}^{-1}$ was increased with time and that is recognized to the quantity of glycerol substitution in the fatty acid by butoxy radicals (butanolysis).

The soybean oil robust band peak is at $1743.6 \mathrm{~cm}^{-1}$ and soybean butyl diesel robust band peak is at 1739.4 $\mathrm{cm}^{-1}$ shifting to peak indicates the transesterification. Absorbance peak of biodiesel was completely separate from that of the soybean oil. The best of absorbance band at frequency $1739.4 \mathrm{~cm}^{-1}$ was accustomed calculate the concentration of ester within the butyl biodiesel layer.

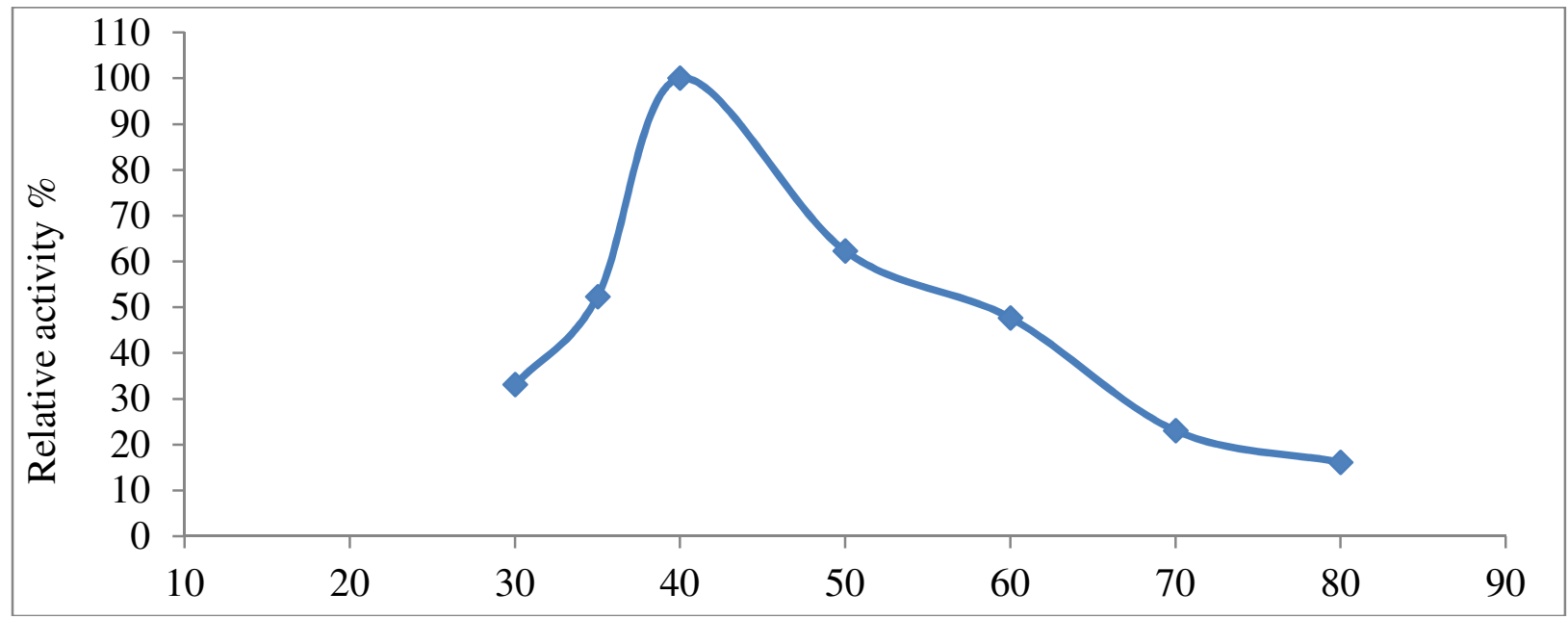

Fig.-3: Effect of reaction temperature on relative activities

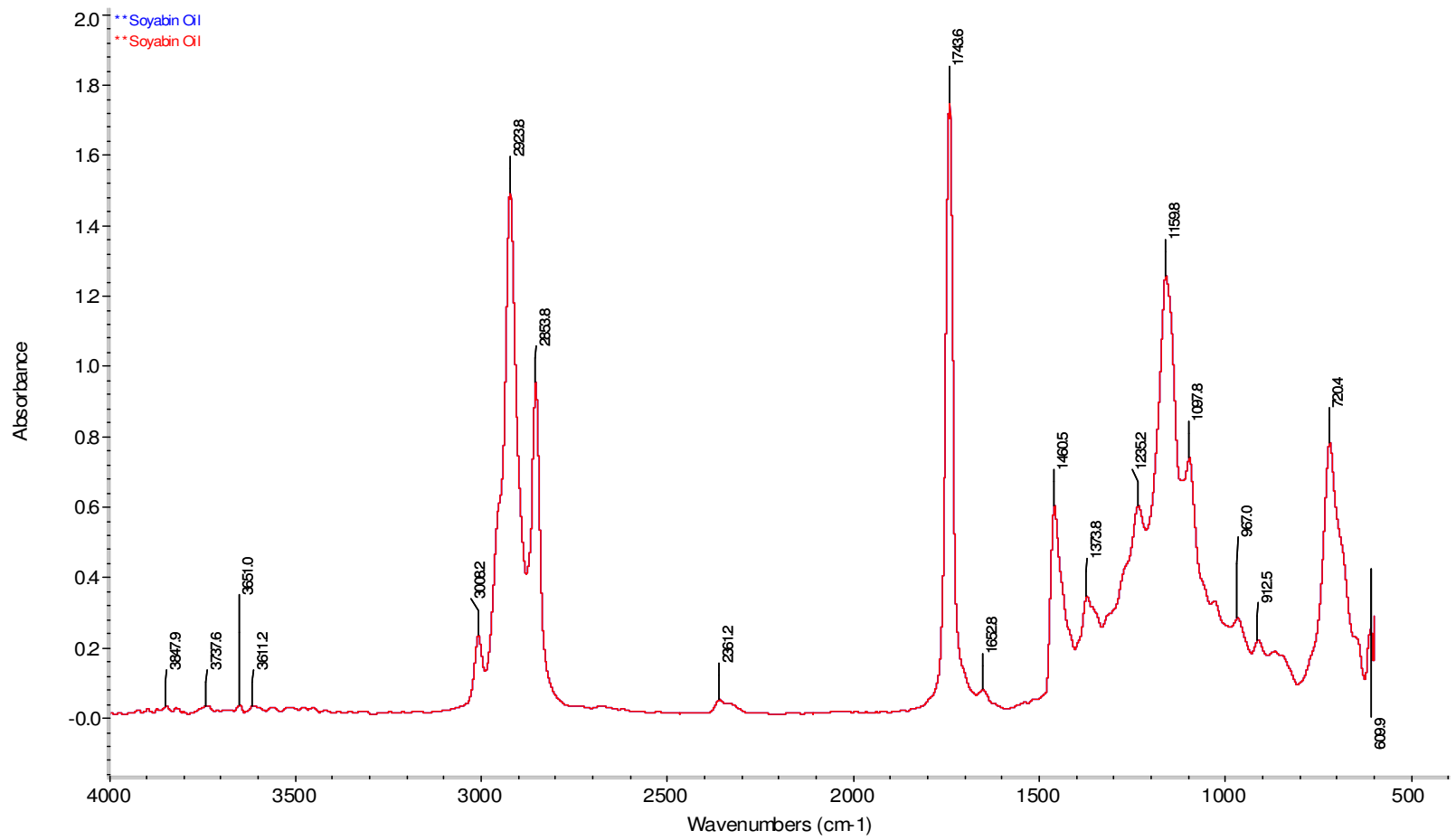

Fig.-4: FTIR peak for soybean oil

Characteristics of soybean oil and biodiesel fuel

A standardization curve was obtained by measure the peak of the $1739.4 \mathrm{~cm}^{-1}$ bands for samples of ester and oil of well-known compositions (Butyl ester and triolein).The Fourier Transform Infrared 
RASĀYAN J. Chem.

Vol. 11 | No. 1 |187-194 | January - March | 2018

spectra of butyl ester and triolein samples at absorbance $1739.4 \mathrm{~cm}^{-1}$ for various concentration. The peak height at $1739.4 \mathrm{~cm}^{-1}$ was modified as a result of modification in the concentration of fatty acid butyl ester (FABE) in the mixture. Therefore a standardization curve between the concentration of FABE and peak height was developed to see the yield of butyl biodiesel.

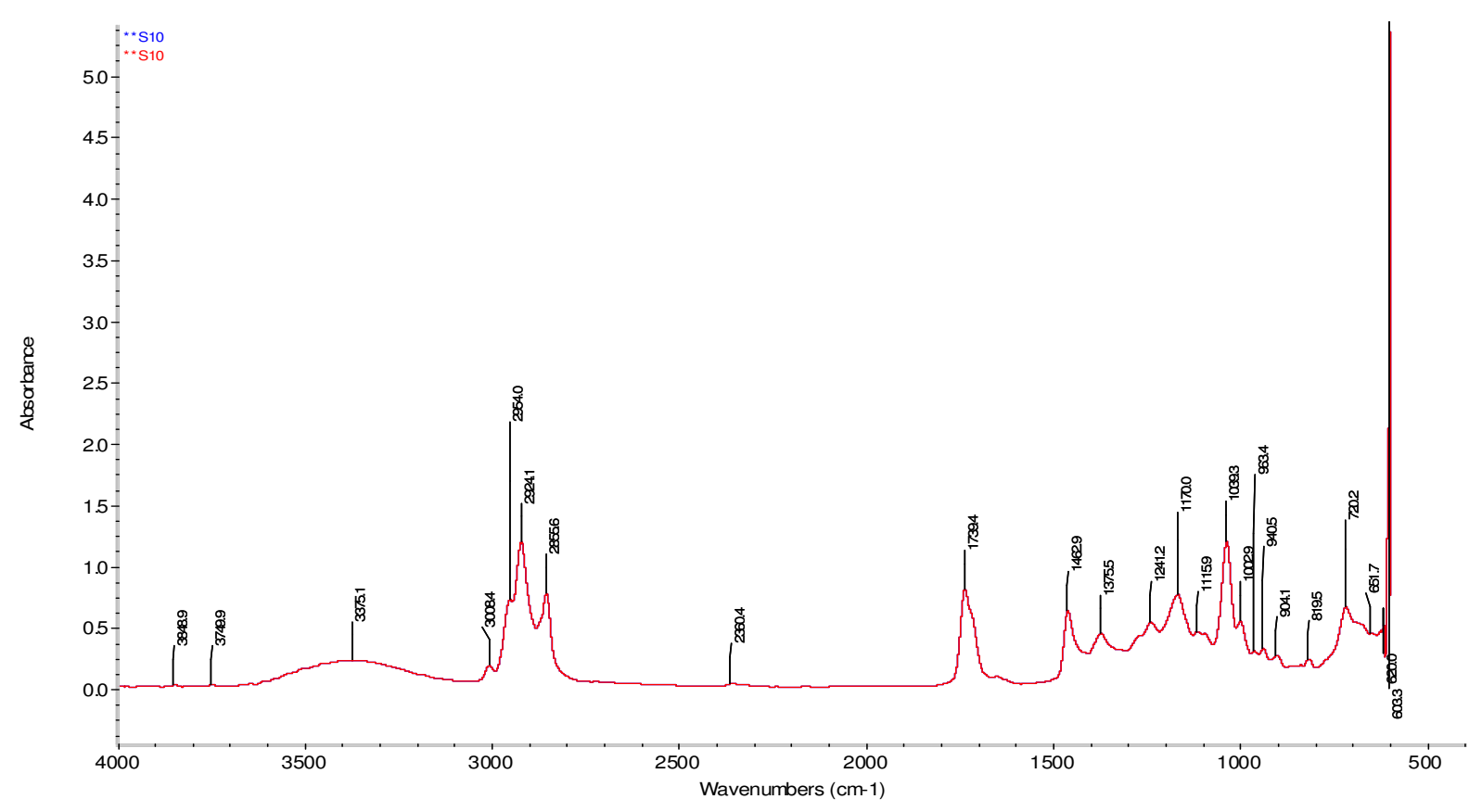

Fig.-5: FTIR peak for butyl biodiesel

Biodiesel yield was calculated in eqn.-1.

$$
\text { Yield }=\mathrm{V}_{\mathrm{c}} \times \mathrm{V}_{\mathrm{l}} / \mathrm{M}_{0}
$$

Where, $\mathrm{V}_{\mathrm{C}}, \mathrm{V}_{\mathrm{l}}, \mathrm{M}_{0}$ are the ester concentration in $(\mathrm{g} / \mathrm{mL})$, butyl biodiesel layer volume in $(\mathrm{mL})$, and weight of soybean oil utilized in $(\mathrm{g})$ severally.

\section{Effect of reaction temperature on biodiesel yield}

Even though increasing temperature affects backward reactions similarly, the influence on forwarding reactions far more pronounced inside the temperature window of biodiesel production. Moreover, implies that temperature favorably influences biodiesel yield even upon the utilization of various homogenous base catalysts or various alcohols. The latter observations preponderantly apply even upon the use of different kinds of catalysis, like acidic or protein. ${ }^{23,24}$

Temperature, none the less, sometimes should be below alcohol boiling point, that promotes the utilization of renewable higher alcohols (bio-ethanol and biobutanol), ought to their value become similar to (relatively inexpensive) methyl alcohol. Although temperature will increase the yield of the alkyl group esters within the entire temperature interval below methyl alcohol (most normally used alcohol) boiling point ${ }^{25}$, that is valid for various oils, alcohols and homogeneous catalysts also, one continuously should acknowledge the reversible nature of chemical reactions, pertinent to transesterification, and therefore the Arrhenius law for each forward and backward reaction. The increase of the product yield with temperature therefore should be tested through an experiment, particularly in cases, during which mechanism is a lot of complicated (e.g. adsorption-reaction-desorption mechanisms, associated with heterogeneous catalysis ${ }^{26}$, or when using the alcohols with higher boiling 
RASĀYAN J. Chem.

Vol. 11 | No. 1 |187-194 | January - March | 2018

points than methyl alcohol, that the extrapolation of product conversion with temperature may come back to a turning point, when backward reactions begin to prevail.

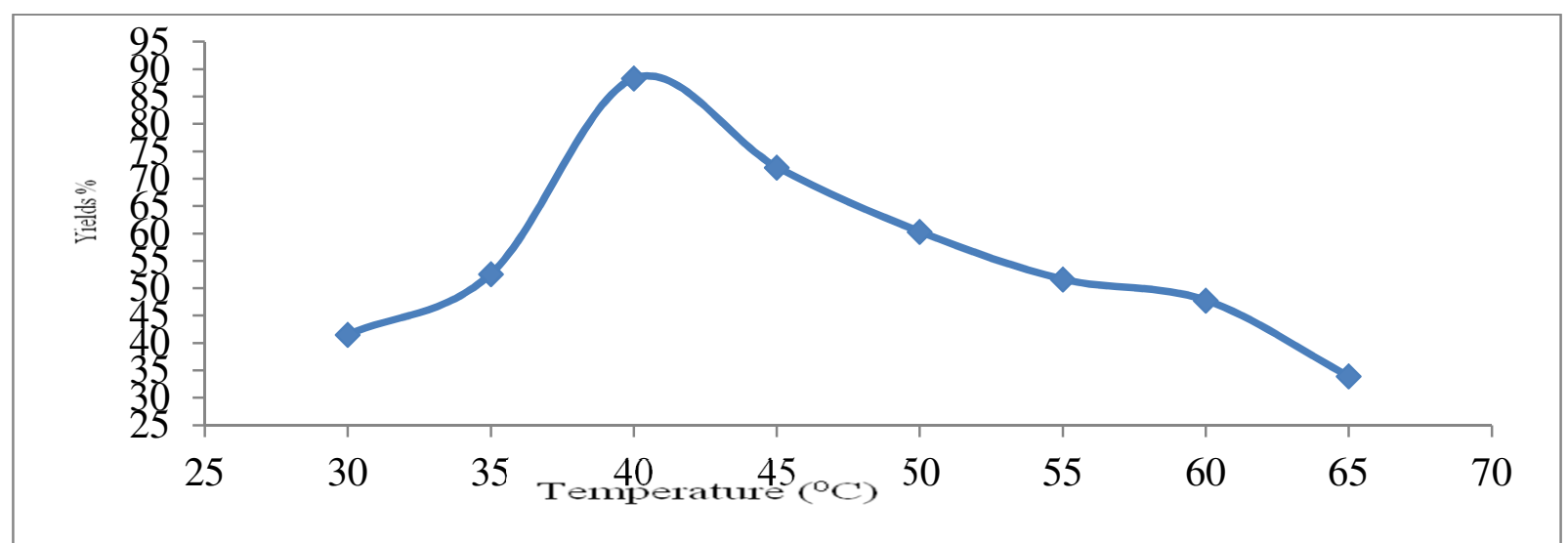

Fig.-6: Biodiesel yield on temperature

Temperature is considered to be one of the important parameters for producing biodiesel as the reaction temperature has a strong impact on the rate of reaction. Structure of the enzymes and proteins strongly influence their activity and they may lose their originality if heated above a particular temperature (optimum temperature). Lipase of Pseudomonas cepacia was used to produce biodiesel from soybean oil and various experiments were performed at different temperatures of $30,35,40,45,50,55,60$ and $65^{\circ} \mathrm{C}$ to investigate the effect of temperature upon the lipase used for the synthesis of biodiesel. In the meantime the molar ratio of iso-butanol to soybean oil was taken as 6:1 along with the addition of $0.00279 \mathrm{~g}$ lipase and put on the water bath shaker at $150 \mathrm{rpm}$ for $48 \mathrm{~h}$. The yields of biodiesel at various temperatures have been plotted in figure 6 . At a temperature of $40^{\circ} \mathrm{C}$, the maximum yield of biodiesel was found to be $88.32 \%$. Figure 6 demonstrates that during the process of transesterification, the yield of biodiesel increased up to the temperature of $40^{\circ} \mathrm{C}$ and denaturation of lipase brought in a decrease after $40^{\circ} \mathrm{C}$. This clearly shows that the maximum yield of biodiesel can be obtained at an optimum temperature of $40^{\circ} \mathrm{C}$.

\section{Properties of butyl biodiesel and soybean oil}

The tests of acid values, kinematic viscosity, flash point and density are performed on the ultimate product. The values obtained were within the range of ASTM D974. Table-2 depicts the parameters at the various steps of the reaction. It had been determined that the necessary parameters like kinematic viscosity and acid value were inside the vary of ASTM D445, ASTM D974 specification. The value of kinematic viscosity was determined and located to be $59.62 \mathrm{~mm}^{2} / \mathrm{s}$ at $40^{\circ} \mathrm{Cand}$ acid value was $0.88 \mathrm{mg} \mathrm{KOH} / \mathrm{g}$. Values of flash point and density were 213 and $0.89 \mathrm{~g} / \mathrm{mL}$ at $30^{\circ} \mathrm{C}$, severally.

Table-2: Properties of butyl biodiesel and soybean oil

\begin{tabular}{c|c|c|c|c}
\hline Properties & Methods & Limits of biodiesel & Butyl biodiesel & Soybean oil \\
\hline Density $\mathrm{g} / \mathrm{mL}$ & ASTM D4052 & $0.87-0.90$ & 0.89 & 0.878 \\
\hline $\mathrm{K}$ viscosity at $40^{\circ} \mathrm{C} \mathrm{mm} / \mathrm{s}$ & ASTM D445 & - & 59.62 & 345.41 \\
\hline Flash point ${ }^{\circ} \mathrm{C}$ & ASTM D93 & $>130$ & 213 & 282 \\
\hline Acid value $\mathrm{mg} / \mathrm{KOH}$ & ASTM D974 & $<0.8$ & 0.88 & 2.23 \\
\hline
\end{tabular}

\section{CONCLUSION}

The interest for biodiesel worldwide is relied upon to increment strongly sooner rather than later. The rivalry of consumable oil sources as nourishment versus fuel makes palatable oil not a perfect feedstock for biodiesel generation. Besides, redirection of land from sustenance or encourage a generation of vitality 
biomass creation will impact nourishment costs. India is currently in the improvement phase of building up expansive scale feedstock generation bases and present-day biofuel creation industrial facilities. In this work butyl biodiesel was prepared enzymatically without immobilization using soybean oil various properties were compared with the standard. FTIR analysis was done to find out the yield due to shifting of the peak $(\mathrm{C}=\mathrm{O})$. Under optimal conditions, butyl esters yield of $88.32 \%$ was achieved. The time required for this yield was found to be $48 \mathrm{~h}$.

\section{ACKNOWLEDGEMENT}

The corresponding author gratefully thanks Ministry of Human Resource Development, India (MHRD) for providing financial support and the Indian Institute of Technology (BHU) for providing lab to conduct the research work.

\section{REFERENCES}

1. R. S. (Pat) Allen, Journal of Agricultural and Food Information, 8(4), 35(2008).

2. M. Prabhahar,S. Sendilvelan, S. Prakash and M. Saravanakumar, Rasayan J. Chem., 10(4), 1075 (2017)

3. A. P. Vyas, A. L. Verma and L. Subrahmanyam, Fuel, 89, 1(2010).

4. P. S. Bisen, B. S. Sanodiya, G. S. Thakur, R. K. Baghel and G. B. K. S. Prasad, Biotechnology Letter, 32(8), 1019(2010).

5. S. Sendilvelan and K. bhaskar, Rasayan J. Chem., 10(3), 1043 (2017)

6. A. Rottig, L. Wenning, D. Broker and A. Steinbuchel, Applied .Microbiology Biotechnology, 85(6), 1713(2010).

7. J. W. Chen and W. T. Wu, Journal of Bioscience and Bioengineering, 95(5), 466(2003).

8. S. Shirin and A Jamal, Rasayan J. Chem., 11(1), 74(2018)

9. K. R. Jegannathan, S. Abang, D. Poncelet, E. S. Chan and P. Ravindra, Critical Reviews in Biotechnology, 28, 253(2008).

10.D. Arnaldo, M. Casquete, E. Millan, V. Sanchez, J. M. Cervero and S. Luque, Ing. Quim., 40(462), 244 (2008).

11.T. Tan, J. Lu, K. Nie, L. Deng and F. Wang, Biotechnology Advances, 28(5), 628(2010).

12.R. A. Sheldon, Advanced Synthesis and Catalysis, 349, 1289(2007).

13.Z. G. Wang, L. S. Wan, Z. M. Liu, X. J. Huang and Z. K. Xu, Journal of Molecular Catalysis B: Enzymatic, 56, 189(2009).

14.S. F. Li, J. P. Chen, and W. T. Wu, Journal of Molecular Catalysis B: Enzymatic, 47, 117(2007).

15.G. Knothe, Fuel Processing Technology, 86, 1059(2005).

16.J. D. A. Rodrigues, J. F. P. D. Cardoso, E. R. Lachter, L. R. M. Estevao, E. Lima and R. S. V. Nascimento, Journal of the American Oil Chemists' Society, 83, 353(2006).

17.S. Sendilvelan and K. Rajan, Rasayan J. Chem., 10(1), 190 (2017)

18.G. A. Macedo, Y. K. Park and G.M. Pastore, Brazilian Journal of Microbiology, 39, 687(1997).

19.T. Hoshino, T. Sasaki, Y. Watanabe, T. Nagasawa and T. Yamane, Bioscience Biotechnology and Biochemistry, 56(4), 660(1992).

20.L. D. C. Ochoa, C. R. Gomez, G. V. Alfaro and R. O. Ros, Enzyme and Microbial Technology, 37, 648(2005).

21.Y. Shimada, Y. Watanabe, T. Samukawa, A. Sugihara, H. Noda, H. Fuduka and Y. Tominaga, Journal of the American Oil Chemists' Society, 76(7), 789(1999).

22.G. F. Zagonel, P. P. Zamora and L. P. Ramos, Talanta, 63, 1021(2004).

23.L. Fjerbaek, K. V. Christensen and B. Norddahl, Biotechnology and Bioengineering, 102, 1298 (2009).

24.M. K. Lam, M. T. Lee and A. R. Mohamed, Biotechnology Advances, 28, 500(2010).

25.B. Likozar and J. Levec, Fuel Processing Technology, 122, 30(2014).

26.F. A. Dawodu, O. Ayodele, J. Xin, S. Zhang and D. Yan, Applied Energy, 114, 819(2014).

[RJC-1813/2017] 